\title{
Replika Benda Kerja meningkatkan Aktivitas Pembelajaran Pekerjaan Dasar Elektromekanik di SMKN 2 Yogyakarta
}

\author{
Endang Retno Lisningrum ${ }^{{ }^{*}}$ \\ ${ }^{1}$ Sekolah Menengah Kejuruan Negeri 2 Yogyakarta \\ ${ }^{1}$ lisningrum@ymail.com* \\ * corresponding author
}

\begin{tabular}{|c|c|}
\hline ABSTRACT & Article Info \\
\hline $\begin{array}{l}\text { The purpose of this study was to improve the learning outcomes of work } \\
\text { materials from non-metallic materials in the subject of Basic Electromechanical } \\
\text { Work (PDE). This research is a two-cycle Classroom Action Research, by } \\
\text { implementing four actions in each cycle, namely: 1) planning, 2) action, 3) } \\
\text { observation, and 4) reflection. The action used is to apply learning with the } \\
\text { assignment method. The teacher gives assignments to students to carry out } \\
\text { learning activities, then students present the results of the assignment. The } \\
\text { learning outcomes of the first cycle, the activities and skills of students are still } \\
\text { low, so that the learning outcomes are also low (below 50\%). In cycle II learning } \\
\text { outcomes, activities and skills experienced positive changes, namely student } \\
\text { activity increased from } 48 \% \text { to 93\%, while skills increased from } 44 \% \text { to } 90 \% \text {, so } \\
\text { that learning outcomes also increased from } 38 \% \text { to } 90 \% \text {. 10\% of students who } \\
\text { are not yet competent because they do not enter and their health is disturbed. The } \\
\text { results of the data analysis indicate that the PDE Practice learning activities by } \\
\text { utilizing a replica of the workpiece using the assignment method can improve } \\
\text { learning outcomes. }\end{array}$ & $\begin{array}{r}\text { Article history } \\
\text { Received: March } 5^{\text {th }}, 2021 \\
\text { Revised: May } 27^{\text {th }}, 2021 \\
\text { Accepted: May } 29^{\text {th }}, 2021 \\
\text { Keywords } \\
\text { workpiece replication, } \\
\text { basic electromechanical } \\
\text { work, } \\
\text { classroom action research. }\end{array}$ \\
\hline ABSTRAK & \\
\hline $\begin{array}{l}\text { Tujuan dari penelitian ini yaitu untuk meningkatkan hasil belajar materi } \\
\text { pekerjaaan dari bahan non logam pada mata pelajaran Pekerjaan Dasar } \\
\text { Elektromekanik (PDE). Studi ini merupakan Penelitian Tindakan Kelas dua } \\
\text { siklus, dengan menerapkan empat Tindakan pada masing-masing siklus, yaitu: 1) } \\
\text { perencanaan, 2) tindakan, 3) observasi, dan 4) refleksi. Tindakan yang digunakan } \\
\text { yaitu dengan menerapkan pembelajaran menggunakan metode penugasan. Guru } \\
\text { memberikan tugas kepada siswa untuk melakukan kegiatan belajar, kemudian } \\
\text { siswa mempresentasikan hasil tugas tersebut. Hasil belajar siklus pertama, } \\
\text { aktifitas dan ketrampilan siswa masih rendah, sehingga hasil belajar juga rendah } \\
\text { (dibawah 50\%). Hasil belajar siklus kedua, aktivitas dan keterampilan mengalami } \\
\text { perubahan positif, yaitu aktifitas siswa naik dari } 48 \% \text { naik menjadi 93\%, } \\
\text { sedangkan ketrampilan naik dari 44\% menjadi } 90 \% \text {, sehingga hasil belajar juga } \\
\text { naik dari 38\% menjadi 90\%. 10\% dari siswa yang belum kompeten dikarenakan } \\
\text { tidak masuk serta terganggu kesehatannya. Hasil analisis data menunjukkan } \\
\text { bahwa aktivitas pembelajaran Praktik PDE dengan pemanfaatan replika benda } \\
\text { kerja menggunakan metode penugasan dapat meningkatkan hasil belajar. }\end{array}$ & \\
\hline
\end{tabular}




\section{PENDAHULUAN}

Pembelajaran merupakan proses interaksi antara peserta didik dengan lingkungannya sehingga terjadi perubahan perilaku ke arah lebih baik. Tugas guru yang paling utama dalam pembelajaran yaitu mengkondisikan lingkungan belajar agar menunjang terjadinya perubahan perilaku bagi peserta didik. Keberadaan guru yang lebih lama disekolah semestinya lebih bermakna bagi pelayanan yang lebih optimal terhadap siswa. Guru bisa memanfaatkan waktu diluar jam mengajar secara produktif, misalnya dengan cara merancang metode pengajaran yang lebih tepat sasaran, menganalisis hasil belajar siswa, berinteraksi yang lebih mendalam terhadap siswa, atau bisa juga dengan mengadakan penelitian untuk mengungkap kasus-kasus problematika belajar dan pengajaran. Semua itu tentu saja berpulang pada pribadi para guru untuk lebih meningkatkan etos kerjanya.

Pendidikan sebagai subsistem dari sistem pembangunan nasional, memiliki peran dan tanggung jawab sebagai penyedia dan pengembangan sumber daya manusia (SDM) sesuai dengan tuntutan kebutuhan pembangunan. Pendidikan Kejuruan, sebagai subsistem Pendidikan nasional, merupakan pendidikan yang berorientasi pada dunia kerja yang salah satu tujuannya yaitu memberikan bekal siap kerja kepada siswa sebagai tenaga kerja tingkat menengah (madya) sesuai persyaratan yang dituntut oleh dunia kerja (Depdikbud ,1985: 283).

Rencana stategis Direktorat Pembinaan SMK tahun 2010 - 2014 yaitu peningkatan akses pendidikan yang berkualitas, terjangkau, relevan, dan efisiensi menuju terangkatnya kesejahteraan hidup rakyat, kemandirian, keluhuran budi pekerti, dan karakter bangsa yang kuat. Pembangunan bidang pendidikan diarahkan demi tercapainya pertumbuhan ekonomi yang didukung keselarasan antara ketersediaan tenaga terdidik dengan kemampuan menciptakan lapangan kerja atau kewirausahaan, serta menjawab tantangan kebutuhan tenaga kerja. (Renstra P.SMK).

Selaras dengan rencana tersebut maka pola Pendidikan, khususnya pembelajaran, di SMK terus dievaluasi dan dikembangkan agar dalam proses kegiatan belajar dan mengajar lebih efektif dan efisien, sehingga peserta didik lebih cepat memiliki ketrampilan sesuai profil kompetensi yang dipersyaratkan. Guru sebagai perencana pengajaran atau kegiatan instruksional, fasilitator dan dinamisator harus mampu memanfaatkan potensi lingkungan yang relevan, baik di dalam maupun di luar sekolah sebagai sumber belajar untuk meningkatkan efektivitas belajar bagi peserta didik.

Tujuan pembelajaran optimal, terdapat beberapa hal yang perlu diperhatikan oleh pendidik, salah satu di antaranya yaitu metodologi mengajar guru dalam memberikan materi pelajaran. Metode penugasan berarti guru memberi tugas tertentu agar siswa melakukan kegiatan belajar, kemudian siswa harus mempertanggungjawabkan atau melaporkan hasil tugas tersebut. Tugas yang diberikan guru dapat berupa masalah yang harus dipecahkan, kemudian prosedurnya tidak diberitahukan agar siswa mencari sendiri prosedur pemecahan permasalahannya.

Mata pelajaran Pekerjaan Dasar Elektromekanik (PDE) pada program keahlian Teknik Instalasi Tenaga Listrik 
(TITL) dengan Kompetensi Dasar (KD) Pekerjaan dari Bahan Non Logam, materi tersebut menggunakan media dalam proses belajar mengajar yaitu replika benda kerja (Darsono, 1979). Replika merupakan tiruan dari bentuk aslinya, dengan kata laian replica benda kerja merupakan bentuk tiruan dari benda aslinya yang terbuat dari bahan yang mudah dibuat (KBBI daring).

Proses belajar mengajar PDE pada kelas X TITL SMKN 2 Yogyakarta masih sebatas ceramah, tanya jawab, demonstrasi, contoh soal, dan penugasan. Siswa mengerjakan tugas berdasarkan contoh soal dan gambar, sehingga belum bisa maksimal menerima materi pelajaran atau penugasan. Oleh karena itu, media replika benda kerja dalam memahami pembelajaran pekerjaan dasar dari bahan non logam mempunyai peran yang sangat penting dalam proses belajar mengajar. Hal ini penting dikarenakan peserta didik SMK berpikir analisis sehingga perlu didukung media pengajaran replika benda kerja untuk mencapai tujuan secara maksimal dalam ranah kognitif, afektif, dan psikomotorik.

$$
\text { Pelajaran PDE dengan materi }
$$
pekerjaan dari Bahan Non Logam merupakan salah satu dari kompetensi keahlian yang harus dituntaskan oleh peserta didik yang orientasi pembelajarannya menitik beratkan pada praktik. Dalam pelaksanannya siswa kurang termotivasi dan kurang aktif dikarenakan metode mengajar yang kurang tepat. Selama ini pembelajaran hanya diberikan dengan teori dan gambar. Karena siswa dituntut untuk dapat melaksanakan keterampilan dengan skill dan pengetahuan seimbang, maka disamping diberikan teori, siswa juga diberikan contoh atau model dan demonstrasi supaya imajinasi dan kreativitasnya muncul. Untuk itu, sebagai pengajar menginginkan sarana dan metode yang dapat membantu meningkatkan motivasi dan aktivitas belajar siswa yang pengaruhnya dapat meningkatkan hasil belajar. Pemanfaatan model atau replika benda kerja kiranya dapat memacu aktivitas anak dengan melihat dan mengamatinya untuk membuat rencana dan menciptakan suatu benda kerja dengan kreatifitasnya sendiri-sendiri. Berdasarkan uraian tersebut diatas maka tujuan Penelitian Tindakan Kelas ini adalah pemanfaatan replika benda kerja dengan metode pemberian tugas untuk meningkatkan aktivitas, keterampilan, dan hasil belajar mata pelajaran PDE pada materi Pekerjaan dari bahan non logam kelas X TITL-1 di SMKN 2 Yogyakarta tahun pelajaran 2018/2019.

\section{METODE}

Penelitian ini merupakan Penelitian Tindakan Kelas (PTK) dengan menggunakan dua siklus dan masingmasing siklus menggunakan empat komponen tindakan, yaitu: perencanaan, tindakan, observasi, dan refleksi dalam satu spiral yang saling terkait (Akbar, 2010). Siklus tindakan disajikan seperti pada Gambar 1.

Penelitian Tindakan Kelas ini dilaksanakan di SMKN 2 Yogyakarta pada bulan Maret sampai dengan bulan Mei 2019. Subjek dari penelitian ini yaitu siswa kelas X TITL-1 Program Keahlian Teknik Listrik sebanyak 31 siswa yang terdiri 27 siswa dengan jenis kelamin laki-laki dan 4 siswa dengan jenis kelamin perempuan. Objek Penelitian ini yaitu replika benda kerja sebagai media pembelajaran untuk meningkatkan hasil belajar siswa. Teknik pengumpulan data yang digunakan dalam penelitian ini adalah observasi, studi 
dokumen, wawancara dan tes. Wawancara terstruktur dengan menemui berbagai informan yaitu guru kelas, kepala sekolah, dan siswa. Pengamatan dilakukan secara langsung dalam kegiatan belajar mengajar untuk memperoleh data tentang proses pelaksanaan pembelajaran di kelas dengan menggunakan media replika benda kerja pada pembelajaran PDE materi pekerjaan dari bahan non logam. Dokumen dalam penelitian tindakan ini berupa dokumentasi tindakan penelitian, serta catatan berupa portofolio. Analisis data dilakukan dengan analisis data deskriptif kuantitatif dan deskriptif kualitatif.

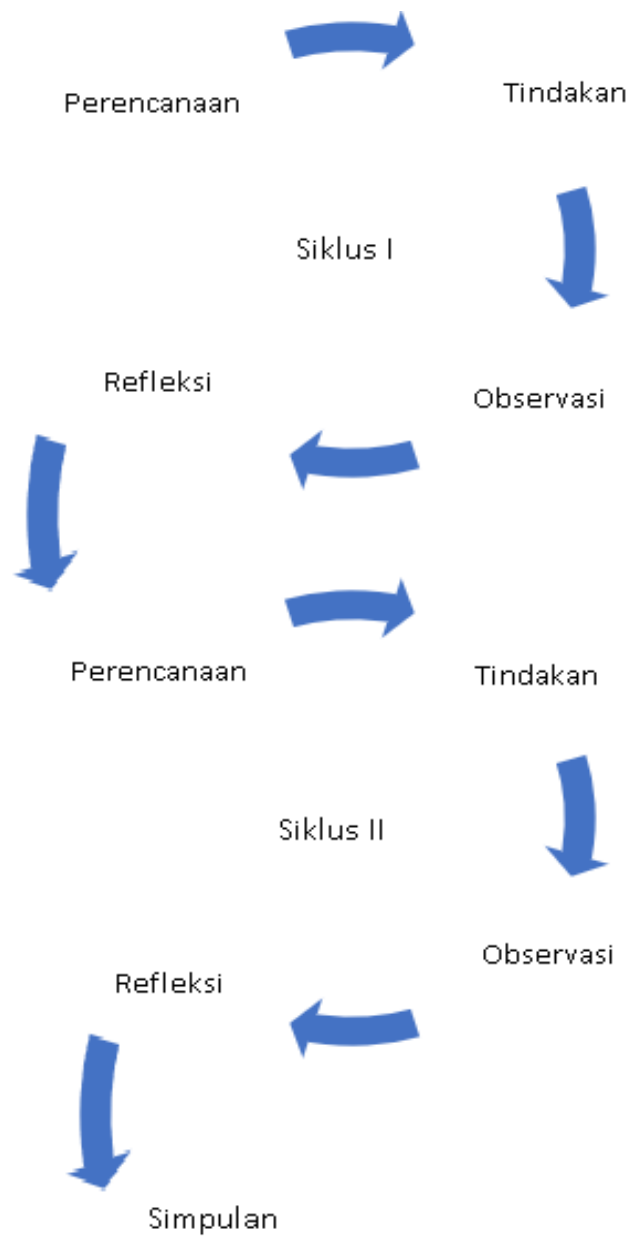

Gambar 1. Siklus Penelitian Tindakan Kelas

\section{HASIL DAN PEMBAHASAN}

Pemanfaatan replika benda kerja dengan metode pemberian tugas dapat meningkatkan aktivitas, keterampilan, dan hasil belajar dalam pembelajaran PDE materi pekerjaan dari bahan non logam kelas X TITL-1 di SMKN 2 Yogyakarta tahun pelajaran 2018/2019 yang diukur melalui dua siklus yang dilaksanakan bulan Maret sampai dengan bulan Mei 2019. Adapun hasil pelaksanaan pengembangan adalah sebagai berikut:

\section{Siklus I}

Siklus pertama, tindakan dilaksanakan pada proses pembelajaran mata pelajaran PDE dengan materi pokok KD 4.7 tentang pekerjaan dari bahan non logam. Proses belajar mengajar untuk penelitian tindakan dilaksanakan dalam $2 \mathrm{x}$ pertemuan dengan rentang waktu tiap pertemuan 4 x 45 menit. Jumlah siswa yang mengikuti sebanyak 30 siswa.

Indikator dalam pertemuan pertama ini, menjelaskan tentang materi Pekerjaan dari bahan non logam dengan pokok bahasan merencana gambar pekerjaan dengan acuan replika benda kerja. Sebelum proses belajar mengajar, guru membagi siswa menjadi 4 kelompok dan memberikan pre-tes selama kurang lebih 20 menit.

Tindakan yang telah dilakukan dalam siklus pertama, memperoleh peningkatan dari rata-rata evaluasi pre-tes post-test yang dilaksanakan sebagai tugas pada pembelajaran siklus pertama pertemuan ke 2. Apabila dilakukan prosentase, dari pretes post-tes siklus pertama yaitu 70.5 menjadi 75.1. Evaluasi hasil belajar yang dilakukan dalam tindakan pada siklus pertama ini telah menunjukkan peningkatan kriteria nilai cukup baik dengan bimbingan dari $23.3 \%$ menjadi $33.3 \%$. Evaluasi 
penyempurnaan tindakan pada siklus pertama pertemuan ke dua, salah satunya adalah dengan bimbingan yang lebih intensif terhadap penggunaan replika benda kerja.

\section{Siklus II}

Siklus kedua dilaksanakan dengan kegiatan utama melakukan perbaikan dengan memfokuskan pada pendalaman materi, meliputi fungsi dari roset yang akan dibuat, estetika harus sesuai dengan peralatan yang akan dipasang pada roset, ada faktor penyebab dari materi pembelajaran yang perlu direfleksi. Salah satunya adalah tugas merancang/merencana.
Kegiatan dalam tindakan penelitian sikus kedua ini, guru meminta siswa untuk melaksanakan praktek pekerjaan dasar bahan non logam. Yaitu membuat roset kayu. Penilaian teori diperoleh dari hasil gambar, dan laporan siswa. Materi tes/penugasan sebagaimana pada soal evaluasi dalam siklus pertama, untuk siklus ke dua ini telah dilakukan penyempurnaan berdasarkan refleksi bentuk gambar garis potong. Terdapat tiga item soal yang dijadikan dasar dalam penilaian, yaitu 1) rencana gambar yang lengkap dengan deskripsi (skor nilai 20), 2) menentukan urutan pekerjaan yang benar dengan gambar (skor nilai 20), 3) hasil pekerjaan baik dan benar (skor nilai 60).

Tabel 1. Kriteria Hasil Belajar Pekerjaan dari Bahan Non-Logam

\begin{tabular}{cccccc}
\hline No. & Kriteria & Interval nilai & $\begin{array}{c}\text { Jumlah } \\
\text { siswa }\end{array}$ & Prosentase & $\begin{array}{c}\text { Rerata } \\
\text { Kelas }\end{array}$ \\
\hline 1 & Sangat baik (sangat kompeten) & $91-100$ & 1 & $3.3 \%$ & - \\
\hline 2 & $\begin{array}{c}\text { Baik ( kompeten tanpa } \\
\text { bimbingan) }\end{array}$ & $81-90$ & 10 & $33.3 \%$ & - \\
\hline 3 & $\begin{array}{c}\text { Cukup baik (kompeten dengan } \\
\text { bimbingan) }\end{array}$ & $76-80$ & 19 & $63.3 \%$ & - \\
\hline 4 & Kurang baik (belum kompeten) & $50-75$ & - & - & - \\
\hline 5 & $\begin{array}{c}\text { Sangat kurang (belum } \\
\text { kompeten) }\end{array}$ & $00-49$ & - & $100 \%$ & 79.86 \\
\hline
\end{tabular}

Berdasarkan Tabel 1 di atas, maka dapat disimpulkan bahwa evaluasi atau penugasan belajar yang dilakukan dalam tindakan PTK pada siklus II dengan kategori baik yaitu sebesar 33,3\%, yang berarti kompeten tanpa bimbingan, bahkan ada peserta didik memperoleh hasil belajar dengan kriteria sangat baik/kompeten sebesar 3,3\%. Dengan demikian, penggunaan media replika benda kerja pekerjaan dasar elektromekanik materi pekerjaan dari bahan non logam dapat meningkatkan hasil belajar siswa kelas $\mathrm{X}$
TITL1 Program keahlian Teknik Ketenagalistrikan di SMK Negeri 2 Yogyakarta.

Tujuan penelitian ini yaitu upaya meningkatkan aktivitas, ketrampilan dan hasil belajar dengan pemanfaatan replika benda kerja dalam pembelajaran pekerjaan dasar elektromekanik materi pekerjaan dari bahan non logam. Upaya peningkatan dilakukan dengan menggunakan media replika benda kerja. Penggunaannya dilaksanakan secara intensif dan cermat mengikuti prosedur dalam setiap Tindakan 
pada siklus pada Penelitian Tindakan Kelas.

Kondisi pada awal pertemuan, siswa hanya menggantungkan penjelasan materi dari guru dengan metode ceramah dan analisa gambar di papan tulis. Situasi seperti ini sangat dominan terjadi pada kondisi awal pembelajaran. Kemudian pada pertemuan tindakan siklus selanjutnya siswa sudah terbiasa belajar dengan media replika benda kerja secara mandiri, walaupun sedikit penjelasan materi inti dari guru, namun bimbingan guru masih diperlukan. Seperti pada tindakan penelitian di siklus I dan siklus II yang terdapat peningkatan hasil belajar. Peran guru tidak lagi mendominasi, tetapi justru siswa yang lebih berkembang dengan mencermati, menganalisa, dan memahami petunjuk. Juga didukung dengan termotivasi untuk bertanya. Ratarata kelas dan ketuntasan meningkat dapat dilihat pada tabel 2 berikut ini.

Tabel 2. Kriteria Ketuntasan Belajar pada Pre Tes, Siklus I dan Siklus II

\begin{tabular}{ccccc}
\hline No. & Kriteria & $\begin{array}{c}\text { Prosentase } \\
\text { Pre-Tes }\end{array}$ & $\begin{array}{c}\text { Prosentase } \\
\text { Siklus I }\end{array}$ & $\begin{array}{c}\text { Prosentase } \\
\text { Siklus II }\end{array}$ \\
\hline 1 & Sangat baik (sangat kompeten) & - & - & $3.3 \%$ \\
\hline 2 & Baik ( kompeten tanpa bimbingan) & $6.7 \%$ & $10 \%$ & $33.3 \%$ \\
\hline 3 & $\begin{array}{c}\text { Cukup baik (kompeten dengan } \\
\text { bimbingan) }\end{array}$ & $23.3 \%$ & $33.3 \%$ & $63.3 \%$ \\
\hline 4 & Kurang baik (belum kompeten) & $66.7 \%$ & $56.7 \%$ & \\
\hline 5 & Sangat kurang (belum kompeten) & $3.3 \%$ & - & - \\
\hline & Ketuntasan & $21 \%$ & $43,3 \%$ & $100 \%$ \\
\hline
\end{tabular}

Berdasarkan Tabel 2 di atas dapat diketahui bahwa ada peningkatan pembelajaran setelah tindakan dilaksanakan, yaitu nilai rata-rata 70,5 pada pre-tes dengan ketuntasan $21 \%$, nilai rata-rata 75,1 pada siklus I dengan ketuntasan 43,3\%, dan nilai rata-rata 79,86 pada siklus II dengan ketuntasan $100 \%$. Pada akhirnya pembelajaran berbasis tindakan ini dapat meningkatkan hasil belajar pembelajaran PDE materi pekerjaan dari bahan non logam dengan media replika benda kerja.

Peningkatan hasil belajar siswa tersebut, yaitu 1) kriteria pencapaian skor evaluasi pada siklus I dengan kategori sangat baik (sangat kompeten) belum tercapai, namun pada siklus II terdapat angka nilai rata-rata $100 \%$ dengan di dalamnya ada 3,3\% sangat kompeten, 2) Kriteria baik (kompeten tanpa bimbingan) terdapat angka $10 \%$ pada siklus I dan meningkat menjadi 33,3\% pada siklus II, 3) Kriteria cukup baik (kompeten dengan bimbingan) terdapat angka $33,3 \%$ pada siklus I meningkat menjadi $63,3 \%$, sedangkan pada siklus II dan diperoleh tuntas $100 \%$, 4) Kriteria kurang baik (belum kompeten/tuntas) dan perlu remedial, terjadi penurunan drastis dari $56,7 \%$ pada siklus I menjadi $0 \%$ pada siklus II.

Dengan demikian, keberhasilan dan rata-rata kelas yaitu pada kondisi akhir pembelajaran yang menunjukkan peningkatan, serta tidak ada siswa yang prestasinya rendah. 


\section{SIMPULAN}

Hasil belajar siswa meningkat dari belum tuntas menjadi tuntas. Rata-rata kelas yaitu 70,5, 75,1, dan 79,86 dengan ketuntasan kelas sebesar 21\%, 43,3\%, dan $100 \%$. Berarti nilai tersebut lebih besar dari standar KKM $(\geq 76)$ dengan kriteria prestasi baik (kompeten tanpa bimbingan) dan amat baik (sangat kompeten). Tahapan tindakan dilaksanakan secara cermat dan intensif melalui penggunaan media replika benda kerja serta pemanfaatan waktu belajar yang meliputi perencanaan (menyiapkan perangkat RPP); implementasi (eksplorasi pengetahuan awal, cermat, memahami, dan membaca/menerapkan secara insentif, penjelasan materi inti, diskusi dan evaluasi); observasi (aktif mengamati kegiatan baik guru maupun siswa), serta merefleksi pembelajaran (melakukan evaluasi atau perbaikan dan penyempurnaan rencana tindakan pembelajaran selanjutnya).

Kegiatan belajar mengajar (KBM) termasuk tes/penugasan materi Pekerjaan dasar dari bahan non logam dilaksanakan secara bertahap. Sub waktu $4 \times 45$ menit yaitu tes/penugasan pertama/pretes tanpa tanpa media replika benda kerja. Selesai langsung ke sub materi dua yang telah disiapkan. Ditambah catatan di papan tulis. Demikian juga sub materi tes/penugasan berikutnya.

\section{DISKUSI}

Guru yang melaksanakan
pembelajaran terutama pembelajaran
dengan menggunakan media replika benda
kerja secara konstektual agar

berkonsentrasi secara insentif untuk meningkatkan kualitas pembelajaran.

Pemanfaatan waktu $4 \times 45$ menit digunakan seefektif dan seefisien mungkin yaitu 5-10 menit pendahuluan, 5-10 menit membaca/mencermati secara cermat dan intensif, 15 menit penjelasan materi inti, dan sisa waktu tersebut dipergunakan untuk mengerjakan butir soal/penugasan. Siswa yang cepat selesai dapat melanjutkan ke sub materi berikutnya. Sementara itu guru mengamati aktivitas belajar dan melakukan koreksi kurang lebih 3 menit perportofolio.

Memilih ketepatan penggunaan metode (ceramah, demonstrasi, dan penugasan) dan media replika benda kerja terhadap kesesuaian materi seperti pembuatan roset dari bahan kayu.

Siswa sebagai pembelajar agar mengikuti prosedur proses belajar mengajar. Siswa mencermati yang selanjutnya menerapkan materi inti pembelajaran PDE materi pekerjaan dari bahan non logam.

\section{DAFTAR RUJUKAN}

Akbar Sa'adun, MpD.Dr.2010. Penelitian Tindakan Kelas, Filosofi, Metodologi \& Implementasi, Yogyakarta: Cipta Media Aksara.

Darsono, Ponijo Agus, 1979, Teori dan Praktek Kejuruan Dasar Listrik, Jakarta: Departemen Pendidikan dan Kebudayaan.

Darsono, Ponijo Agus, 1979. Petunjuk Praktek Listrik, Jakarta: Departemen Pendidikan dan Kebudayaan.

Depdiknas, 2003. Penelitian Tindakan Kelas, Jakarta: Depdiknas. 
Kamus Besar Bahasa Indonesia Daring,

https://kbbi.kemdikbud.go.id/

2016. Diakses pada laman 